\title{
Changing Times for Eastern United States Blackberries
}

\author{
John R. Clark ${ }^{1}$
}

AdDitional INDEX WORDs. small fruits, $R u b u s$, plant breeding

\begin{abstract}
Summary. Eastern U.S. blackberries ( $R u b u s$ subgenus $R u b u s$ ) have advanced in recent years in production and quality of cultivar choices. Mainly a pick-yourown and local sales item of the early 1990s and before, the increased presence of blackberries in retail grocery stores in the last 10 years has broadened the market for this small fruit. Cultivars that can be shipped and have extended shelf life have been the cornerstone of this expansion. Also, off-season production in Mexico has provided fruit for retail marketing during most months of the year. Further advances in production, marketing, and consumption can be achieved with the continuation of improved cultivar development and expansion of production technology.
\end{abstract}

\section{Introduction and background}

$\mathrm{E}$ astern North American (east of the Rocky Mountains) blackberries have long been a favorite wild fruit, as several species grow along fences, highways, edges of forests, and similar locations. Natural hybrids of wild species provided several of the first named cultivars including: 'Eldorado' (Rubus allegheniensis $\times R$. argutus), and 'Lawton' and 'Dorchester' ( $R$. allegheniensis $\mathrm{x} R$. frondosus) (Hall, 1990; Moore, 1984). These selections from the wild were introduced in the mid 1850s (Moore, 1984). 'Brewer,' a wild selection of unknown species origin (likely $R$. pergratus $\times R$. frondosus)(Hall, 1990; Moore, 1997), was released in the early 1920s.

More modern developments that followed were the release of 'Darrow' by Cornell's New York State Agricultural Experiment Station in 1958 (a cross of two 'Eldorado' $x$ 'Brewer' hybrids) and 'Brazos' by Texas A\&M University in 1959 (a second-generation hybrid from 'Lawton' $x$ 'Nessberry') (Moore, 1997). The release of the first thornless, semi-erect-caned cultivars, Smoothstem and Thornfree, in 1966 was significant. These had in their backgrounds 'Eldorado' and 'Brainerd' (released in 1932; a hybrid of 'Himalaya' $x$ an unnamed eastern U.S., erect cultivar, possibly 'Georgia Mammoth'), along with the English cultivar Merton Thornless that pro-

Department of Horticulture, University of Arkansas, Fayetteville, AR 72701

${ }^{1}$ Professor. vided the source of thornless genes (Scott and Ink, 1966).

I provide this brief background of origins of some major early cultivars and parent sources to set the tone for the following discussion on the changing times for eastern U.S. blackberries. It think it very important to keep in mind where this improvement effort began and to be reminded of how close we remain to those early wild selections that were the basis for the initial commercial blackberry production in the eastern U.S.

Major breeding objectives in continuing blackberry improvement have been generally quite straightforward. First, most breeders emphasized large fruit size. This continued focus has resulted in very large-fruited current cultivars such as 'Kiowa' (Moore and Clark, 1996) and 'Chesapeake' (Clark and Finn, 2002). Fruit weight can exceed $15 \mathrm{~g}(0.53 \mathrm{oz})$ on primary fruits of these cultivars. Erect cane architecture has been a common focus, particularly in the University of Arkansas program (Moore, 1984), and a number of erect-caned cultivars have been released. Increased yield potential was a major focus of the U.S. Department of Agriculture (USDA) program, and is best exemplified in the high-yielding 'Chester Thornless' (Galletta et al., 1998). Thornlessness has been desired in most breeding programs, with the USDA program leading the way in the development of several semi-erect thornless cultivars, followed by thornless, erect cultivars from the University of Arkansas. Plant hardiness and disease resistance have been parallel areas of focus in all breeding programs. 


\section{How far had we come by the early 1990s?}

A survey of eastern U.S. production in 1990 indicated blackberries were marketed in the following ways: $62 \%$ pick-your-own, 36\% pre-picked fresh market (mainly on-farm or local fruit stand sales), and 2\% processed (Clark, 1992). The survey results did not indicate that any production was for shipping to distant markets. In this survey, production area increased 56\% from 1980 to 1990 , with a further projected $66 \%$ increase in production area from 1990 to 2000. Again, this increase was envisioned to be largely marketed locally. In the early 1990s, blackberries were not found on grocery store shelves across the U.S (some were present on the west coast), due mainly to the lack of postharvest handling capability of cultivars released prior to that time. Please note again that this discussion is for eastern U.S. production, as a limited amount of production for shipping was being done in California and Oregon.

Some of the new cultivars just beginning to be planted in the early 1990s were found to have fruit firmness adequate for shipping. 'Chester Thornless' displayed a good level of firmness and shelf life, and in the world picture became a major shipping berry later in the decade (J.R. Clark, unpublished). The Arkansas-released cultivar Navaho was found to have excellent shelf life (Moore and Clark, 1989; Perkins-Veazie et al., 1997). Subsequent releases from Arkansas included 'Arapaho' (Moore and Clark, 1993) and 'Apache' (Clark and Moore, 1999), each of which had fruit capable of withstanding shipping. Another key advantage to these Arkansas cultivars is their resistance to the devastating disease double blossom/rosette (caused by Cercosporella rubi) which is common in the southern U.S., and to which most of the previous thorny cultivars were highly susceptible (Buckley et al., 1995). These cultivars have contributed to a major shift in the production outlook for shipping of blackberries from that of a local-marketed crop to one shipped for retail marketing.

\section{Time changes things: The mid to late 1990s}

A major development occurred during this period: the shipping of blackberries to the U.S. from Chile and
Guatemala. Soon thereafter, the development of production technology in central Mexico increased availability of eastern U.S.-developed blackberries. Mexican production is centered in the highlands of the state of Michoacan, and utilizes a number of techniques to force mainly U.S. developed, mediumchill cultivars to flower and fruit in an area of very low chill (J. Lopez-Medina, personal communication). The fruit is harvested from mid October until late April or early May in this region, and currently provides fresh blackberries for U.S. grocery shelves during the winter months. Mexican production has supplanted Chilean blackberry shipping to the U.S. due to less expensive transportation costs of trucking fruit from Mexico compared to air freight required to move blackberries from Chile. The presence of berries in the marketplace in the winter and late spring enhanced the consumer's awareness of blackberries as a grocery item rather than a local item picked on a farm or from wild plants.

American berry shippers (in the eastern and western U.S.) also took note of the expanded potential of blackberries in the shipping market, spurred by the success of the Mexican berries shipped and marketed during the "off" season. These marketers felt that if off-season sales could be this successful, why not have expanded marketing during the "normal" U.S. berry production seasons? This has led to an expansion in acreage grown for shipping between 2001 and 2004, particularly in southern Georgia, Arkansas, Texas, and North Carolina. As a blackberry breeder, it is exciting to see this expansion of the "fourth" berry-as the blackberry was referred to by a major eastern U.S. berry broker-to market with the more popular strawberry (Fragaria xananassa), blueberry (Vaccinium spp.), and red raspberry ( $R$. ideaus).

Local production for pick-yourown, farmers markets, or on-farm sales has also increased recently, though it is difficult to determine trends in this area due to few production statistics being available. However, the expanding number of thornless cultivar options, enhanced fruit quality, and increased interest in berry consumption for human health benefits should positively impact this type of production.

\section{The opportunity: Designing blackberries for a range of growers and consumers}

A great opportunity exists to expand blackberry production in the eastern U.S. and elsewhere. The key area for expansion is in shipping sales, and breeding efforts can focus very specifically for this use. I suggest that with this opportunity, the following model be considered:

genotype $\times$ environment $\times$ consumer $=$ phenotype utilized

This model includes the classic genotype $\times$ environment $=$ phenotype equation that serves as a basis for plant breeding, but includes a greater consideration of the consumer. I follow with a discussion of each input component of this equation and how I see the current situation unfolding.

The GenOTYPE: FRUIT. I believe the most important opportunity for improving the consumption of eastern U.S. blackberries is to enhance the sweetness of berries along with reduced acidity and astringency levels. Often consumers have a memory of tart blackberries, either from the wild or from very tart cultivars. Tart berries function well if cooked or processed, particularly if sugar is added to the product. Shipped berries, however, are usually eaten fresh. Our breeding goal should be to enhance blackberry flavor, human health benefits, and convenience. Breeding sweeter berries can largely be achieved by selecting for higher levels of soluble solids or reduced acidity, or both. Too low acidity levels can lead to berries having a "flat" flavor. Current cultivars vary in levels of soluble solids, with 'Navaho' one of the sweetest, usually $12 \%$ in fully ripe berries. Associated flavors provided by volatiles (Perkins-Veazie et al., 2000) and other compounds are important to round out the flavor of the berries. Selections in the Arkansas breeding program have achieved 15\% soluble solids, a result of crossing high soluble solids parents.

Seed size and "presence in mouth feel" is a concern to many consumers, in that smaller seeds (pyrenes) are more desirable. Seeds can also vary in surface smoothness and pulp adherence, both traits that are preferred to make the seeds less noticeable when consumed (Hall, 1990). Fortunately, seed size is highly heritable with partial 
dominance for small seed size (Moore et al., 1975).

Parallel to enhanced eating quality, the berries must be capable of arriving on market shelves in an attractive form. This means maintaining firmness and uniform black color, and being free from leakage and decay. Enhanced firmness can be achieved in parent selection to produce very firm progeny to the point of near "crisp" berries (J.R. Clark, personal observation). However, storage evaluation must be conducted since firmness and uniform color of fruit evaluated in the field may not be a true indicator of ultimate firmness in storage (Perkins-Veazie et al., 1996). 'Chester Thornless', Navaho', and 'Arapaho' perform well in maintaining color and having reduced leakage compared to common thorny cultivars (Galletta et al., 1998; Perkins-Veazie et al., 1999). Kidd et al. (2004) found a range of postharvest fruit resistance among blackberry genotypes, with 'Kiowa' and 'Navaho' among the best cultivars; they also found Botrytis cinerea to be the predominant pathogen on berries showing decay.

The genotype: Plant. Thornlessness continues to be a primary plant trait desired by growers. This trait has little interest by the consumer, unless for pick-your-own operations where it is of paramount importance, or for home-garden production. Although thorny cultivars continue to be important in the eastern U.S., they are in reduced desirability since more thornless cultivars are available that are erectcaned and offer higher quality berries for shipping. Most growers prefer erect canes, as these plants do not require as much care in trellising and tying canes as the semi-erect cultivars. One challenge is to enhance yields on erect types to nearer those of semi-erects. For instance, 'Chester Thornless' often produces fruit yields approximately two times that of 'Navaho' (Galletta et al., 1998; Moore and Clark, 1989). Winter hardiness continues to be the major limitation of blackberry production in the midwestern and eastern U.S. and in more northern areas. 'Chester Thornless' continues to be the best choice among thornless cultivars for mid-winter hardiness (Galletta et al., 1998). Efforts are minimal for breeding enhanced hardiness in the eastern U.S. Double blossom/rosette resistance for the southern U.S. is critical for blackberry production, and the resistance of the Arkansas thornless cultivars continues to minimize this disease problem.

The most exciting development in blackberry plant alteration in recent years has been the incorporation of primocane fruiting. The first two commercial cultivars of this plant type were released in 2004 as Prime-Jan (University of Arkansas, Fayetteville) (cultivar APF-8) and Prime-Jim (University of Arkansas, Fayetteville) (cultivar APF-12) (Clark et al., 2004). These are intended for home gardens and very limited commercial trial. They lack the fruit quality required for shipping. However, subsequent cultivars should provide enhanced quality and it is hoped these can be incorporated into the shipping profile of eastern U.S. blackberries in the next decade. The primocane trait will allow the following benefits: 1) two crops (summer and late summer to fall) should be possible if floricanes are successfully overwintered, 2) fall fruiting will provide production at a time (September and October) when blackberry fruit is in very short supply, 3 ) cold injury to overwintering canes can be eliminated if only the primocane crop is produced, 4) pruning can be simplified if only the primocane crop is produced, since mowing canes could be utilized, and 5 ) overwintering pests may be reduced or eliminated.

The environment. The environment is not commonly considered as an alterable element in crop production, at least in terms of plant breeding. With berry crops, particularly blackberries, environmental or cultural modifications will play a potentially large role in future production. The evaluation of new genotypes in these environments will also expand potential breeding progress. The use of "high" or "Spanish" tunnels is increasing dramatically in world berry production to alter time and length of fruiting and eliminate, or greatly decrease, rainfall impacts on fruit quality. For instance, use of high tunnels for extended fall production in moderate climates might be very successful, particularly with primocanefruiting cultivars.

Additionally, blackberry production has undergone great area expansion in recent years, particularly to lower-chill areas such as central Mexico and Guatemala. Cultural modifications applied to medium- to lower-chill cultivars including defoliation and growth regulator applications, have expanded production of blackberries. These methods will likely be used in other lower-chill regions of the world. Genotypes with reduced chill, and/or more adaptation to these cultural inputs, will enhance production in these environments.

The Consumer. As a plant breeder, one of the challenges that can occur is: What does the customer demand in a new cultivar? Who exactly is the customer? Blackberry breeders currently have the opportunity to work closely with brokers/shippers to design the preferred genotype for shipping, be it the appropriate size, shape, flavor, shelf life, or other fruit characteristic. The brokers/shippers are very interested in new developments as they work to expand the marketing of blackberries. Likewise, nurseries are usually in tune with grower and homeowner desires, and can be another source of input on new genotypes and their development. Two recent examples come to mind, both involving fruit size. 'Apache' blackberry produces berries up to $10 \mathrm{~g}$ $(0.35 \mathrm{oz})$, but these can be a problem in that they are often too large for common clamshell containers used in shipping; learning this concern has shifted the target in breeding at Arkansas from "the larger the better" to a smaller size of 7-8 g (0.25-0.28 oz) as optimum. In the USDA, Corvallis, Ore., program a small berry selection is planned for release that will be used in mixed-fruit frozen packs since the smaller berries blend well with other components in the pack (C. Finn, personal communication). Again, the clear communication between breeder and customer is providing for the use of genotypes that may never enter the commercial arena otherwise. Is this communication unique in fruit breeding? Probably not, but it is rather unique for blackberries as the industry expands, and new ideas and uses surface.

Finally, the blackberry consumer may be unique across the U.S. Agreed, most prefer sweet berries. However, throughout the country there is variation in what is the preferred blackberry flavor. Most people in the eastern U.S. are more familiar with the eastern U.S. native blackberry flavor, while western U.S. inhabitants are more accustomed to the fine aromatic flavors of cultivars such as 'Marion', which is from the Ursini section, or raspberry $\mathrm{x}$ black- 
berry hybrids 'Boysen' and 'Logan'. This provides a unique opportunity for breeders and marketers, in that a range of flavors can be potentially marketed. These flavors can also be combined by breeding into more unique flavors, further broadening the scope of this trait.

\section{Closing comments}

This "fourth" berry, the fairly recently domesticated blackberry, has a unique opportunity for expanded use because of a current combination of factors including breeding, marketing, and promotion. In reviewing what has been achieved thus far in breeding, and envisioning what can further be accomplished in breeding coupled with close work with marketers and consumers, it appears the greatest potential for blackberries lies ahead. These are truly "changing times for eastern U.S. blackberries," and I believe they are changing for the better!

\section{Literature cited}

Buckley, J.B., J.N. Moore, and J.R. Clark. 1995. Blackberry cultivars differ in susceptibility to rosette disease. Fruit Var. J. 49:235-238.

Clark, J.R. 1992. Blackberry production and cultivars in North America east of the Rocky Mountains. Fruit Var. J. 46:217-222.

Clark, J.R. and C.E. Finn. 2002. Blackberry and hybrid berries. In: W.R. Okie (ed.). Register of new fruit and nut varieties list 44. HortScience 37:251.

Clark, J.R. and J.N. Moore. 1999. 'Apache' thornless blackberry. HortScience 34:1291-1293.

Clark, J.R., J.N. Moore, and J. Lopez-Medina. 2004. Primocane-fruiting blackberry cultivar releases for the University of Arkansas. HortScience 39:662 (Abstr.).

Galletta, G.J., A.D. Draper, J.L. Maas, R.M. Skirvin, A.G. Otterbacher, H.J. Swartz, and C.K. Chandler. 1998. 'Chester Thornless' blackberry. Fruit Var. J. 52:188-122.
Hall, H.K. 1990. Blackberry breeding. Plant Breeding Rev. 8:249-312.

Kidd, J.P., J.R. Clark, P. Fenn, and B.J. Smith. 2004. Evaluation of postharvest disease resistance in blackberry cultivars. Horticultural studies 2003. Ark. Agr. Expt. Sta. Res. Ser. 520:18-19.

Moore, J.N. 1984. Blackberry breeding. HortScience 19:183-185.

Moore, J.N. 1997. Blackberry,p. 161-173. In: The Brooks and Olmo register of fruit and nut varieties. 3rd ed. ASHS Press, Alexandria, Va.

Moore, J.N. and J.R. Clark. 1989. 'Navaho' thornless blackberry. HortScience 24:863-865.

Moore, J.N. and J.R. Clark. 1993. 'Arapaho' erect thornless blackberry. HortScience 28:861-862.

Moore, J.N. and J.R. Clark. 1996. 'Kiowa' blackberry. HortScience 31:286-288.

Moore, J.N., C. Lundergan, and E.D. Brown. 1975. Inheritance of seed size in blackberry. J. Amer. Soc. Hort. Sci. 100:377-379.

Perkins-Veazie, P., J.R. Clark, D.J. Huber, and E.A. Baldwin. 2000. Ripening physiology in 'Navaho' thornless blackberries: Color, respiration, ethylene production, softening, and compositional changes. J. Amer. Soc. Hort. Sci. 125:357-363.

Perkins-Veazie, P., J.K. Collins, and J.R. Clark. 1996. Cultivar and maturity affect postharvest quality of fruit from erect blackberries. HortScience 31:258-261.

Perkins-Veazie, P., J.K. Collins, and J. R. Clark. 1999. Cultivar and storage temperature effects on the shelflife of blackberry fruit. Fruit Var. J. 53:201-208.

Perkins-Veazie, P., J.K. Collins, J.R. Clark, and L. Risse. 1997. Air shipment of 'Navaho' blackberry fruit to Europe is feasible. HortScience 32:132.

Scott, D.H. and D.P. Ink. 1966. Origination of Smoothstem and Thornfree blackberry varieties. Fruit Var. Hort. Dig. 20:31-33. 